Laszlo Bardosi MD PhD, ${ }^{1}$ Attila Bardosi MD, ${ }^{2}$ Hans-Joachim Gabius PhD ${ }^{3}$

\title{
Changes of expression of endogenous sugar receptors by polymor- phonuclear leukocytes after prolonged anaesthesia and surgery
}

\begin{abstract}
Anaesthesia and surgery are known to depress granulocyte function in the early postoperative period, leading to deterioration of the immune defence against infection. Carbohydratelectin interactions may play an important role in the activities of phagocytic cells in that they facilitate initial host defence in the event of microbial antigenic challenge. A panel of biotinylated (neo)glycoproteins (chemically glycosilated carrier proteins) was used to detect endogenous carbohydrate-binding receptors hectins/, on peripheral blood polymorphonuclear leukocytes of patients undergoing prolonged anaesthesia for replantation surgery. Four hours afier induction of anaesthesia, a progressive decline of expression of endogenous sugar receptors on granulocytes was detected using the labelled (neo)glycoproteins lactose-BSA, $N$-acetyl-D-glucosamine-BSA, D-mannose-BSA, sialic-acid-BSA and D-xylose-BSA. Concomitant changes in peripheral white blood cell counts and the lack of depression in the absence of general anaesthetic agents suggested the existence of a possible relationship between reduced expression of (neo)glycoprotein receptors to impaired granulocyte function and anaesthetic-induced immunodepression.
\end{abstract}

\section{Key words}

ANAESTHESIA;

BLOOD: leukocytes;

COMPLICATIONS: immunological depression.

From the 'Institute of Anaesthesia and Intensive Therapy, Medical University of Pécs, Hungary; ${ }^{2}$ Institute of Pathology, Academic Hospital of University of Münster, Detmold, Germany; ${ }^{3}$ Max-Planck-Institute for Experimental Medicine, Department of Chemistry, Göttingen, Germany.

${ }^{1}$ Supported by a fellowship from the Max-Planck-Society.

Address correspondence to: Dr. L. Bardosi, Institute of Anaesthesia and Intensive Therapy, Medical University of Pécs, 7643 Pécs, Ifjuság u. 13. Hungary.

Accepted for publication 7th October, 1991.
Nous savons que l'anesthésie et la chirurgie dépriment la fonction des granulocytes dans la période postopératoire immédiate, provoquant une détérioration de la défence immunitaire contre l'infection. Les interactions hydrate de carbone-lectine pourraient jouer un rôle important dans les activités des cellules phagocytaires en façilitant la défense initiale de l'hôte lors d'une confrontation avec des antigènes microbiaux. Un panneau de (néo) glycoprotéines liées à la biotine (protéines porteuses glycosilées chimiquement) a été utilisé pour détecter les récepteurs endogènes se liant aux hydrates de carbone, les lectines, dans les leucocytes polymorphonucléaires du sang périphérique de patients subissant une anesthésie prolongée dans le cadre d'une chirurgie de réimplantation. Quatre heures après l'induction de l'anesthésie, une diminution progressive de l'expression des récepteurs endogènes de sucre sur les granulocytes a été détectée en utilisant les (néo) glycoprotéines marquées lactose$B S A, N$-acétyl-D-glucosamine-BSA, D-mannose-BSA, acide sialique-BSA et D-xylose-BSA. Les changements concomitants dans les décomptes des globules blancs périphériques et le manque de dépression en l'absence d'agents anesthésiques généraux ont suggéré l'existence d'une relation possible entre une expression diminuée des récepteurs des (néo) glycoprotéines et la fonction granulocitaire altérée, et l'immunodépression induite par l'anesthésie.

General anaesthesia and surgery are known to influence immune cell function. The consequent impairment of defence mechanisms leads to a higher risk of postoperative infection. The clinical manifestation is dependent on several factors, i.e., inherited conditions of the immune system, secondary immunodeficient states due to malnutrition, underlying malignant disease, immunosuppressive therapy as well as the degree of surgical trauma, the length of operation and the type of anaesthetic technique used.

Peripheral blood polymorphonuclear leukocytes (PMNL) are involved in the first line defence against invading microorganisms. The depressive effect of nitrous 
oxide on actively replicating tissues is well known. Experimental administration of halothane with nitrous oxide in vitro and clinical observations on patients anaesthetized with the nitrous oxide-halothane-oxygen technique revealed marked depression of phagocytic and metabolic activity lasting for as long as the first postoperative week. ${ }^{1-4}$

In spite of several theories the mechanism by which anaesthetic agents exert their deleterious effect on granulocyte functions is not known.

Attachment or binding of target cells or particles to phagocytes is a prerequisite for engulfment, internalisation and destruction. Phagocytes must therefore be able to recognize their targets. It has been found that carhohydrate molecules on cellular glycoconjugates participate in recognition as well as other events of cellular immune defence. ${ }^{5}$ The carbohydrate part of glycoconjugates, due to its structural diversity, is thought to serve as a carrier of biological information. The putative existence of an information code system based on carbohydrate-protein interactions calls for the presence of specific carbohydratebinding proteins, lectins, within the cell.

The integrity of these receptors is presumably not only a prerequisite of effective phagocyte function; they also may serve as possible markers for stages of cell differentiation and activation, and also may partake in recirculation and homing processes. ${ }^{6-8}$

On the basis of these assumptions, we analyzed the expression of these specific endogenous sugar receptors on peripheral blood PMNL by means of a panel of labelled (neo)glycoproteins. The aim of the work was to investigate whether the level of expression of these receptors is influenced by prolonged exposure to anaesthetic agents and surgery.

\section{Methods}

Peripheral blood PMNLs were investigated in nine patients who underwent elective replantation surgery of digits from their feet onto their hands. The surgery was performed under general anaesthesia.

\section{Anaesthetic technique}

No premedication was given. Anaesthesia was induced with thiopentone $\left(3 \mathrm{mg} \cdot \mathrm{kg}^{-1}\right)$. Succinylcholine $(1 \mathrm{mg}$. $\mathrm{kg}^{-1}$ ) was administered to facilitate tracheal intubation. Myoneural blockade was maintained with alcuronium at an initial dose of $0.2 \mathrm{mg} \cdot \mathrm{kg}^{-1}$ with $5 \mathrm{mg}$ supplements. Anaesthesia was maintained by controlled ventilation with nitrous oxide $70 \%$ and halothane $0.5 \%$ in oxygen. Fentanyl $(0.05-0.1 \mathrm{mg})$ was given to provide analgesia if required. During the operation the patients received Ringer's lactate and normal saline infusions. No blood transfusion was given. The duration of surgery and anaesthesia averaged eight hours, after which muscle relaxation was reversed with neostigmine $\left(0.05 \mathrm{mg} \cdot \mathrm{kg}^{-1}\right)$ and atropine $(0.02 \mathrm{mg}$. $\mathrm{kg}^{-1}$ ).

Peripheral blood samples and blood films were taken before the induction of anaesthesia (sample $A$ ), at four hours (sample B), and at six hours (sample C). The last sample (D) was taken at the end of surgery (at eight hours), before the administration of the reversal of muscle relaxant. Further samples - a, b, c and d - were obtained with identical timing, from three additional patients who were operated upon under local anaesthesia using $1 \%$ lidocaine solution. The patients were allocated randomly into this group and served as further controls to assess the impact of anaesthetic agents relative to other factors such as surgical trauma.

Absolute leukocyte count was established with a Coulter counter (Mod. FN, Coulter Electronics, GBR) and differential leukocyte counts were obtained based on evaluation of Wright-Giemsa stained blood smears with a light microscope.

\section{Glycocytochemistry}

Peripheral blood films obtained during anaesthesia were glycocytochemically examined. For determination of the expression of endogenous sugar receptors with different carbohydrate specificities in the granulocytes, various labelled (neo)glycoproteins were used: for $\beta$-galactosidespecific receptors by different protocols: lactose(diazo)(BSA-biotin) and the naturally occurring but chemically desialylated asialofetuin-biotin; $\mathrm{N}$-acetyl-D-glucosamine(BSA-biotin) for receptors with specificity to $\mathrm{N}$-acetylated carbohydrates, commonly present in glucoconjugates; for $\alpha$-glucoside-specific receptors: maltose-(BSA-biotin); for $\alpha$-fucoside-specific receptors: $L$-fucose-(BSA-biotin); for $\alpha$-mannoside-specific receptors: $D$-mannose-(BSAbiotin); for $\beta$-xyloside-specific receptors: $D$-xylose-(BSAbiotin); for receptors with an affinity to the commonly occurring $\mathrm{N}$-acetyl-neuraminic acid: sialic-acid-(BSAbiotin). Their synthesis, quality control and biotinylation have been described in detail elsewhere. ${ }^{9-12}$

\section{Glycocytochemical reaction}

For detection of endogenous carbohydrate-binding proteins in PMNLs by specific protein-carbohydrate interaction, glycocytochemical reactions were performed using a standardized protocol. ${ }^{9,10}$

1 The smears were air-dried and fixed in $4 \%$ glutaraldehyde-paraformaldehyde solution.

2 The endogenous peroxidase activity was inhibited by $2 \%$ methanolic hydrogen peroxide (10 min).

3 The slides were preincubated with $0.1 \%$ bovine serum albumine (BSA) -0.1 M phosphate buffer (PBS, pH 7.4) solution for $20 \mathrm{~min}$ to minimize the nonspecific binding 
of BSA-biotin derivatives used in the following steps.

4 Incubation was performed using the different biotinylated carbohydrate-BSA conjugates (carbohydrate-BSAbiotin) or modified, naturally occurring glycoproteins (asialofetuin-biotin) at room temperature for $90 \mathrm{~min}$.

To ascertain the specificity of (neo)glycoprotein binding, further smears were preincubated at room temperature with homologous unlabelled carbohydrate-BSA conjugates (45 min) at a concentration of $20 \mu \mathrm{g} \cdot \mathrm{ml}^{-1}$ to mask sugar specific receptors. Incubation was then performed for 90 min with a mixture (in a relation of 1:100) of labelled carbohydrate-BSA conjugates and the corresponding unlabelled (neo)glycoprotein as competitive inhibitor. In the case of naturally occurring glycoproteins, desyalilated by heat treatment in acidic solution, an excess of lactosylated BSA was applied as inhibitor to exclude considerable contribution of protein-protein interaction. Heterologous unlabelled carbohydrate-BSA conjugate, namely mannose-BSA, was employed as an additional control to inhibit binding of $\beta$-galactoside-specific probes. To prove absence of protein-protein interaction under these conditions, a further control was performed, using only labelled BSA which carries no sugar moieties. 5 After washing in PBS, the smears were incubated with Vectastain ABC Kit (Avidin DH and biotinylated horsredish peroxidase complex $\mathrm{H}$, Vector Laboratories, Burlingame, USA) for $60 \mathrm{~min}$.

6 Washing was performed three times in PBS. The smears were then incubated in 3,3-diaminobenzidine 4- $\mathrm{HCl}$ (DAB) $\cdot \mathrm{H}_{2} \mathrm{O}_{2}$ mixture for $20 \mathrm{~min}$ or in a modified DAB mixture to allow enhancement of weak peroxidase reaction not reliably detectable by simple incubation. ${ }^{13}$ After rinsing in tap water for $10 \mathrm{~min}$, the smears were counterstained with fast green and covered with Entellan.

7 The blood films were then examined with a light microscope.

The investigator was blinded to the preparations which were identified by code numbers after the completion of the assessment. Only PMNLs were evaluated for staining intensity and were graded semiquantitatively in four categories: strong reaction covering the whole or part of the nucleus $=3$; clear, even, but weaker reaction leaving the nucleus free $=2$; weak, patchy staining $=1$; no reaction $=0$ (Figure 1).

Values are expressed as mean \pm SD. The incidence of PMNL with different staining intensity was statistically analyzed using the Chi square test. The scores for 100 cells in each preparation were calculated. The occurrence of negative PMNLs, expressed as a percentage of counted cells, was also noted. Student's $t$ test for paired dependent observations was used for statistical comparisons among WBC counts.

\section{Results}

\section{Sample A}

Peripheral white blood cell (WBC) counts averaged $5.6 \times$ $10^{9} \mathrm{~L}^{-1}$. The differential count indicated the presence of about $67 \%$ neutrophil granulocytes with segmented nucleus, a normal proportion of metamyelocytes, lymphocytes, monocytes and a few eosinophils.

Prior to evaluation of the staining pattern of cells with glycocytochemical reaction, the specificity of proteincarbohydrate interaction was ascertained by specific absence of reaction following incubation in the presence of the appropriate unlabelled (neo)glycoprotein as competitive inhibitor. Staining was also not detectable after the standard procedure if the biotinylated but nonglycosilated carrier protein (BSA) was used.

The glycocytochemical reaction was localized mainly in the cytoplasm of PMN cells, sometimes covering the whole or part of the segmented nucleus (Figures $1 \mathrm{a}-\mathrm{b}$ ). The high incidence of these two staining patterns was apparent in the preoperative samples. The number of granulocytes giving no reaction with labelled (neo)glycoproteins was negligible (Tables I, II and Figure 1c). No difference between metamyelocytes and matured granulocytes with segmented nuclei could be established as far as their endogenous sugar-receptor-expression was concerned (Figure 2).

\section{Sample B}

Although increased WBC counts were observed four hours after the induction of anaesthesia the difference did not reach statistical significance. Differential counts revealed a high percentage of matured granulocytes, no change in metamyelocyte number and a decrease of lymphocyte percentage from $31 \%$ in sample A to $23 \%$ in sample B (Table 1). The overall carbohydrate-binding capacity of granulocytes in sample B scored similar values to that of sample A. Although the density of receptors with $\alpha$ glucoside, $\alpha$-fucoside and $\beta$-xyloside specificity appeared to be slightly hindered, no increase in the number of grade 0 cells occurred (Table II).

\section{Sample $C$}

Six hours of anaesthesia and surgery brought about notable quantitative and qualitative changes. Peripheral WBC count reached $9 \times 10^{9} \mathrm{~L}^{-1}$, preserving the high proportion of neutrophils with segmented nuclei. Glycocytochemical investigations revealed two distinct groups of endogenous sugar receptors. Those underscoring the values which had been observed at sample B included receptors with specificity to lactose(diazo)-BSA, $\mathrm{N}$-acetylglucosamineBSA, mannose-BSA, sialic acid-BSA and xylose-BSA. Either no change or enhanced positivity characterized the 


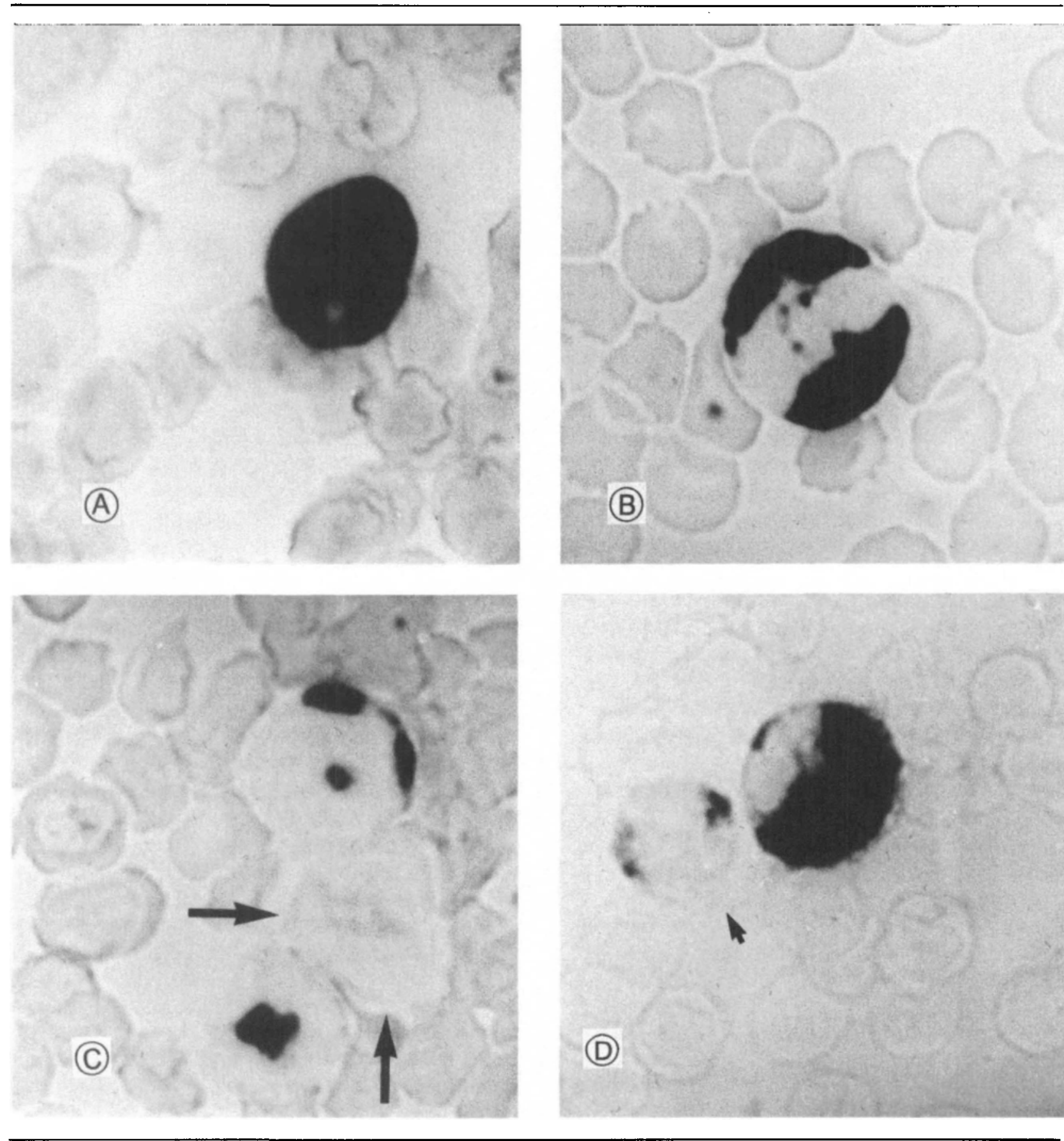

FIGURE 1 Staining pattem of polymorphonuclear leukocytes demonstrating the expression of endogenous sugar receptors with biotinylated (neo) glycoproteins. $(A)=$ grade $3 ;(B)=$ grade 2 ; $(C)=$ grades 1 and 0 (arrows); (D) weak expression of endogenous lectins in a lymphocyte (arrow) compared to a strong (grade 2) reaction of a neutrophil granulocyte: A-C lactose-(BSA-biotin), D mannose-(BSA-biotin); $(1400 \times)$.

receptors in the other group. Data in Table II indicate that the lower receptor-expression-score in the former group was partially due to the appearance of nonreacting (grade 0) cells. However, a generally weaker reaction with more grade 1 granulocytes at the cost of grade 2 and 3 cells also contributed to these findings.

\section{Sample $D$}

The last sample was taken after eight hours of anaesthesia when surgery was terminated. The administration of halothane was turned off and the lungs were ventilated with $50 \%$ nitrous oxide in oxygen for $15 \mathrm{~min}$. No drugs to reverse neuromuscular blockade were given before blood 
TABLE I Positivity scores of carbohydrate-binding receptors on granulocytes during long-term anaesthesia and surgery

\begin{tabular}{|c|c|c|c|c|c|}
\hline \multirow{2}{*}{$\begin{array}{l}\text { Receptor } \\
\text { specificity }\end{array}$} & \multirow[b]{2}{*}{ Neoglycoprotein } & \multicolumn{4}{|c|}{ Scores of samples $/ 100$ cells } \\
\hline & & $A$ & $B$ & $C$ & $D$ \\
\hline B-galactoside & Lactose(diazo)BSA & $\begin{array}{c}256 \pm 16 \\
(240 \pm 20)\end{array}$ & $\begin{array}{c}173 \pm 19 \\
(224 \pm 23)\end{array}$ & $\begin{array}{c}99 \pm 15 \\
(240 \pm 12)\end{array}$ & $\begin{array}{c}33 \pm 4^{*} \\
204 \pm 7)\end{array}$ \\
\hline & Asialofetuin-BSA & $\begin{array}{c}212 \pm 13 \\
(216 \pm 17)\end{array}$ & $\begin{array}{c}189 \pm 7 \\
(193 \pm 6)\end{array}$ & $\begin{array}{c}187 \pm 15 \\
(210 \pm 14)\end{array}$ & $\begin{array}{c}204 \pm 15 \\
(204 \pm 14)\end{array}$ \\
\hline n-acetylated sugar & $\mathrm{N}$-acetylglucosamine-BSA & $\begin{array}{c}210 \pm 17 \\
(198 \pm 12)\end{array}$ & $\begin{array}{c}194 \pm 11 \\
(186 \pm 14)\end{array}$ & $\begin{array}{r}68 \pm 12 \\
(176 \pm 8)\end{array}$ & $\begin{array}{c}36 \pm 8^{*} \\
(198 \pm 14)\end{array}$ \\
\hline$\alpha$-glucoside & Maltose-BSA & $\begin{array}{c}198 \pm 11 \\
(227 \pm 20)\end{array}$ & $\begin{array}{c}174 \pm 11 \\
(211 \pm 18)\end{array}$ & $\begin{array}{c}181 \pm 14 \\
(217 \pm 17)\end{array}$ & $\begin{array}{c}197 \pm 11 \\
(187 \pm 13)\end{array}$ \\
\hline$\alpha$-fucoside & Fucose-BSA & $\begin{array}{c}222 \pm 15 \\
(220 \pm 12)\end{array}$ & $\begin{array}{c}194 \pm 11 \\
(212 \pm 6)\end{array}$ & $\begin{array}{c}210 \pm 8 \\
(175 \pm 7)\end{array}$ & $\begin{array}{c}230 \pm 10 \\
(225 \pm 13)\end{array}$ \\
\hline$\alpha$-mannoside & Mannose-BSA & $\begin{array}{c}183 \pm 12 \\
(185 \pm 12)\end{array}$ & $\begin{array}{c}195 \pm 17 \\
(181 \pm 6)\end{array}$ & $\begin{array}{c}103 \pm 8 \\
(196 \pm 15)\end{array}$ & $\begin{array}{c}80 \pm 5^{*} \\
(184 \pm 8)\end{array}$ \\
\hline Sugar with a carboxyl group & Sialic acid-BSA & $\begin{array}{c}194 \pm 12 \\
(192 \pm 11)\end{array}$ & $\begin{array}{c}165 \pm 12 \\
(177 \pm 18)\end{array}$ & $\begin{array}{r}86 \pm 10 \\
(182 \pm 5)\end{array}$ & $\begin{array}{r}50 \pm 6^{*} \\
(163 \pm 13)\end{array}$ \\
\hline$\beta$-xyloside & Xylose-BSA & $\begin{array}{c}191 \pm 18 \\
(198 \pm 12)\end{array}$ & $\begin{array}{c}120 \pm 12 \\
(193 \pm 14)\end{array}$ & $\begin{array}{c}54 \pm 11 \\
(199 \pm 20)\end{array}$ & $\begin{array}{c}9 \pm 3^{*} \\
(189 \pm 10)\end{array}$ \\
\hline WBC $\times 10^{9} \mathrm{~L}^{-1}$ & & $\begin{array}{c}5.6 \pm 0.4 \\
(5.3 \pm 0.7)\end{array}$ & $\begin{array}{c}6.4 \pm 0.7 \\
(7.1 \pm 1.1)\end{array}$ & $\begin{array}{c}9.0 \pm 1.2 \\
(9.8 \pm 2.8)\end{array}$ & $\begin{array}{c}14.0 \pm 3.5^{*} \\
(16.0 \pm 4.1)\end{array}$ \\
\hline GSEG \% & & $\begin{array}{c}67 \pm 8 \\
(64 \pm 4)\end{array}$ & $\begin{array}{c}70 \pm 8 \\
(68 \pm 6)\end{array}$ & $\begin{array}{c}66 \pm 7 \\
(76 \pm 4)\end{array}$ & $\begin{array}{c}66 \pm 9 \\
(60 \pm 8)\end{array}$ \\
\hline MM & & $\begin{array}{c}3 \pm 1 \\
(4 \pm 1)\end{array}$ & $\begin{array}{c}5 \pm 2 \\
(6 \pm 2)\end{array}$ & $\begin{array}{c}13 \pm 6 \\
(14 \pm 4)\end{array}$ & $\begin{array}{c}15 \pm 4^{*} \\
(15 \pm 5)^{*}\end{array}$ \\
\hline LY & & $\begin{array}{c}31 \pm 6 \\
(30 \pm 5)\end{array}$ & $\begin{array}{c}23 \pm 8 \\
(21 \pm 3)\end{array}$ & $\begin{array}{c}16 \pm 6 \\
(20 \pm 4)\end{array}$ & $\begin{array}{c}14 \pm 2^{*} \\
(18 \pm 3)^{*}\end{array}$ \\
\hline
\end{tabular}

Samples were taken preoperatively $A ; 4$ hours $B ; 6$ hours $C ; 8$ hours $D$ after the induction of anaesthesia. Local anaesthesia cases in brackets. $\mathrm{WBC}=$ white blood cell count; $\mathrm{GSEG}=$ granulocytes with segmented nucleus; $\mathrm{MM}=$ metamyelocyte; $\mathrm{LY}=$ lymphocyte. ${ }^{*}=P<0.001$ compared with preoperative values.

sampling. The changes which had been observed previously in sample $C$ were greater in sample $D$. White blood cell count was found to be $14 \times 10^{9} \mathrm{~L}^{-1}$ with lymphopenia and an increased percentage of metamyelocytes. This is shown in Table I which also demonstrates striking differences in receptor expression. In one group of probes the reaction with three out of five (neo)glycoproteins was almost completely abolished and the reduction of positivity was also apparent with the remaining two probes. The accumulation of negative cells in this category was noted (Figure 2c).

Receptors with specificity to asialofetuin, maltose and fucose preserved their staining pattern and in the case of fucose receptors the avidity seemed even stronger showing a high number of grade 3 cells (Figure 2d).

\section{Discussion}

In our work the staining reaction with a panel of biotinylated (neo)glycoproteins in human PMNL provided evidence for the presence of endogenous sugar receptors with different specificities. The phagocytic response to external pathogenic challenge was prompt: there was an increase in the number of phagocytes and enhancement of their motility and bactericidal activity.
General anaesthesia and surgery are factors which may upset phagocytic function and lead to deterioration in host defence mechanisms. ${ }^{14,15}$ Postoperative leukocytosis with lymphocytopenia - as seen in our patients - is quite common and is thought to be precipitated by endogenous steroid and catecholamine release due to surgical stress. ${ }^{15-18}$ However, it has been questioned whether this increase in the number of leukocytes is linked to enhanced functional capabilities. Indeed, a decrease in phagocytic activity and leukocyte metabolism has been demonstrated under such circumstances. The mechanisms behind these phenomena are still the matter of controversy. ${ }^{3,17-19}$

Various factors are considered to be essential for cell differentiation, activation and cell-to-cell interactions, such as adhesion and recognition. Cell surface glycoconjugates and their endogenous complementary receptors (lectins) seem to represent a carbohydrate-mediated recognitive system different from mechanisms operating during immunophagocytosis. ${ }^{5,20,21}$ Recognition and biosignalling are especially relevant for granulocytes in a variety of activities including phagocytosis, accessory functions during immune response and the physiological traffic of cells from the blood stream to the extravascular tissue. ${ }^{20,21}$ In the light of the impaired expression of endogenous 


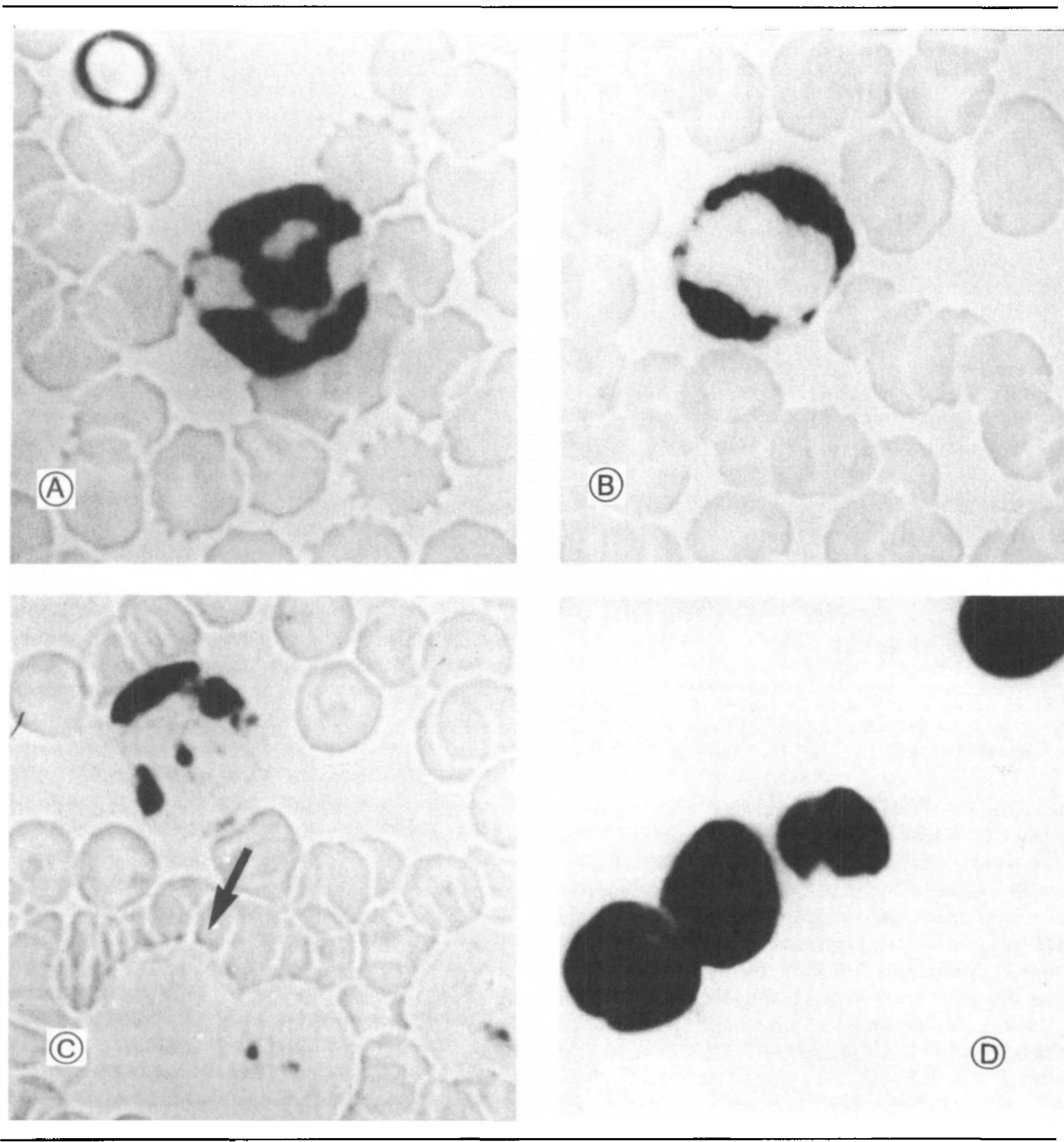

FIGURE 2 A-C. (A-B) Staining pattern of polymorphonuclear leukocytes on different stages of development. No difference in intensity of endogenous lectin expression between metamyelocyte and matured neutrophil (both scoring grade 2) can be established with light microscopy. (C) The predominance of grade 1 and grade 0 (arrow) cells in sample $D$ indicates a depression of mannose-specific receptor expression in neutrophil granulocytes ( $\alpha$-D-mannoside-BSA-biotin reaction); (D) Increased density of $\alpha$-L-fucoside receptors in sample $D$. The majority of granulocytes scored grade 3 with biotinylated fucose-BSA probe. A-D $1400 \times$.

sugar receptors which may be considered to be a consequence of prolonged anaesthesia and surgery, theoretically, the high peripheral WBC count at the end of surgery may be, at least partially, due to a loss or damage of granulocyte sugar receptors, rendering the cells incapable of leaving the bloodstream. Investigations with monoclonal antibodies revealed a lack of certain protein complexes in the membrane of neutrophil leukocytes obtained from patients whose WBCs failed to migrate from the intravascular space to the site of infection, 
TABLE II Percentage of endogenous carbohydrate-binding receptor negative granulocytes during prolonged anaesthesia and surgery

\begin{tabular}{|c|c|c|c|c|c|}
\hline & & $A$ & $B$ & $C$ & $D$ \\
\hline \multirow[t]{2}{*}{$\beta$-galactoside } & Lactose (diazo)-BSA & $\begin{array}{c}2 \\
(0)\end{array}$ & $\begin{array}{c}1 \\
(1)\end{array}$ & $\begin{array}{l}27 \\
(2)\end{array}$ & $\begin{array}{l}52 \\
(0)\end{array}$ \\
\hline & Asialofetuin-BSA & $\begin{array}{c}0 \\
(1)\end{array}$ & 0 & 2 & $\begin{array}{c}0 \\
(1)\end{array}$ \\
\hline \multirow[t]{2}{*}{$\mathrm{N}$-acetylated sugar } & $\mathrm{N}$-acetylglucosamine-BSA & 2 & 3 & 11 & 70 \\
\hline & & (0) & (3) & (0) & (2) \\
\hline a-glucoside & Maltose-BSA & $\begin{array}{c}3 \\
(6)\end{array}$ & $\begin{array}{c}1 \\
(1)\end{array}$ & $\begin{array}{c}4 \\
(2)\end{array}$ & $\begin{array}{c}1 \\
(4)\end{array}$ \\
\hline$\alpha$-fucoside & Fucose-BSA & $\begin{array}{c}0 \\
(6)\end{array}$ & $\begin{array}{l}5 \\
(1)\end{array}$ & $\begin{array}{c}3 \\
(3)\end{array}$ & $\begin{array}{c}1 \\
(2)\end{array}$ \\
\hline$\alpha$-mannoside & Mannose-BSA & $\begin{array}{c}2 \\
(4)\end{array}$ & $\begin{array}{c}0 \\
(2)\end{array}$ & $\begin{array}{l}22 \\
(1)\end{array}$ & $\begin{array}{l}14 \\
(2)\end{array}$ \\
\hline $\begin{array}{l}\text { Sugar with a } \\
\text { carboxyl-group }\end{array}$ & Sialic acid-BSA & $\begin{array}{c}1 \\
(1)\end{array}$ & $\begin{array}{c}3 \\
(3)\end{array}$ & $\begin{array}{l}28 \\
(5)\end{array}$ & $\begin{array}{c}9 \\
(4)\end{array}$ \\
\hline B-xyloside & Xyloside-BSA & $\begin{array}{c}0 \\
(0)\end{array}$ & $\begin{array}{c}1 \\
(1)\end{array}$ & $\begin{array}{l}21 \\
(5)\end{array}$ & $\begin{array}{l}79 \\
(2)\end{array}$ \\
\hline
\end{tabular}

Samples were taken preoperatively A; four hours B; six hours C; eight hours D after the induction of anaesthesia. (Local anaesthesia cases in brackets.)

resulting recurrent infections. These studies did not, however, prove that these protein complexes were in their nature sugar receptors. ${ }^{22,23}$

The other possibility that cells with poor endogenous lectin expression represent different granulocyte populations recruited into the bloodstream either via detachment from the marginating pool or release from the bone marrow stores may also serve as plausible explanation. On the other hand, the strong lectin expression we observed also in metamyelocytes denied the possibility that the changes in receptor expression in sample $C$ and $D$ could be related to immatured cells released into the circulation as a result of surgery-induced stress response.

Endogenous lectins of macrophages and lymphocyte subpopulations and their involvement in immune reactions have been widely investigated. ${ }^{24,25}$ Several studies have proved their importance in lymphocyte development, adhesion, activation and homing mechanisms as well as in the broad spectrum of macrophage activities. ${ }^{7,21,24-27}$ However, information on the significance of endogenous lectins in PMNL is scanty. Mannose-specific lectins were found to be responsible for attachment, ingestion and destruction of certain bacteria such as $\mathrm{E}$. coli by human neutrophils. Receptors for the closely related N-acetyl-Dglucosamine also function in phagocytosis. The $\mathrm{L}$-fucosespecific lectins mediate rapid plasma clearance of lysosomal glycosides with terminal L-fucose or mannose residues. ${ }^{28-31}$

Our results show that the expression of granulocyte sugar-binding receptors was suppressed by prolonged general anaesthesia. This observation has independently been confirmed in animal models using different inhalational agents when no surgery was performed. ${ }^{32}$ Further- more, in our series of clinical observations, surgery performed under local anaesthesia failed to produce any change in PMNL lectin expression. Such models will be helpful to clarify the clinically important causes behind the development of postoperative granulocytosis and secondary immunodepression.

\section{Acknowledgements}

The authors wish to thank W. Hannemann, H. Brodmerkel and L. Kaschewski for their excellent assistance. This study was supported by the D. M. Scheel-Stiftung für Krebsforschung.

\section{References}

1 Bruce DL, Koepke JA. Changes in granulopoiesis in the rat associated with prolonged halothane anesthesia. Anesthesiology 1966; 27: 811-6.

2 Nunn JF, O'Morain C. Nitrous oxide decreases motility of human neutrophils in vitro. Anesthesiology 1982; 56: 45-8.

3 Bardosi $L$, Tekeres $M$. Impaired metabolic activity of phagocytic cells after anaesthesia and surgery. $\mathrm{Br} J$ Anaesth 1985; 57: 520-3.

4 Brodsky JB, Baden JM, Serra $M$ et al. Nitrous oxide inactivates methionin synthetase activity in rat testis. Anesthesiology 1984; 61: 66-8.

5 Sharon $N$. Carbohydrates as recognition determinants in phagocytosis and lectin-mediated killing of target cells. Biol Cell 1984; 51: 239-46.

6 Clohisy DR, Bar-Sharit Z, Chappel JC et al. 1,25-Dihydroxivitamin D3 modulates bone marrow macrophage precursor proliferation and differentiation. J Biol Chem 1987; 262: 15922-9. 
7 Stoolman LM, Tenforde TS, Rose SD. Phosphomannosyl receptors may participate in the adhesive interaction between lymphocytes and high endothelial venules. J Cell Biol 1984; 99: 1535-40.

8 Matsuoka T, Tavassoli $M$. Purification and partial characterisation of membrane-homing receptors of two cloned murine hemopoietic progenitor cell line. J Biol Chem 1989; 264: 20193-8.

9 Gabius H-J, Bardosi A. Neoglycoproteins as tools in glycohistochemistry. Prog Histochem Cytochem 1991; 22: 3-19.

10 Bardosi A, Dimitri T, Gabius H-J. (Neo)glycoproteins as tools in neuropathology: histochemical patterns of the extent of expression of endogenous carbohydrate-binding receptors, like lectins, in meningeomas. Virchows Arch (B) 1988; 65: 35-43.

11 Gabius H-J, Bodanowitz S, Schauer A. Endogenous sugar-binding receptors in human breast tissue and benign and malignant breast lesions. Cancer 1988; 61: 1125-31.

12 Gabius H-J, Kohnke B, Hellmann T et al. Comparative histochemical and biochemical analysis of endogenous receptors for glycoconjugates in human and pig nerve. $J$ Neurochem 1988; 51: 756-65.

13 Bardosi A, Dimitri T, Behrends $T$ et al. Is part of the molecular basis of the perineurial barrier function the lack of endogenous carbohydrate-binding proteins. J Neurosci Res 1989; 22: 65-73.

14 Koenig A, Koenig UD, Stoeckel H. Anästhesie und Immunologie. Eine übersicht. Pract Anästh 1978; 13: 415-29.

15 Hole $A$. Depression of monocytes and lymphocytes by stress-related humoral factors and anaesthetic related drugs. Acta Anaesth Scand 1984; 28:280-6.

16 Walton $B$. Anaesthesia, surgery and immunology. Anaesthesia 1978; 33: 322-8.

17 Welch WD. Halothane reversibly inhibits human neutrophil bacterial killing. Anesthesiology 1981; 55: 650-4.

18 Moudgil GC, Pandya AR, Ludlow DJ. Influence of anaesthesia and surgery on neutrophil chemotaxis. Can Anaesth Soc J 1981; 28: 232-8.

19 Moudgil GC, Allan RB, Russell RJ et al. Inhibition, by anaesthetic agents, of human leukocyte locomotion towards chemical attractants. Br J Anaesth 1977; 49: 97-105.

20 Vandenbroucke-Grauls CMJE, Thijessen HMWM, Verhoef $J$. Interaction between human polymorphonuclear leukocytes and Staphylococcus aureus in the presence and absence of opsonins. Immunology 1984; 52: 427-31.

21 Ofek I, Sharon $N$. Lectinophagocytosis: a molecular mechanism of recognition between cell surface sugars and lectins in the phagocytosis of bacteria. Infect Immun 1988; 56: $539-47$.
22 Harlan JM, Killen PD, Senecal FM et al. The role of neutrophil membrane glycoprotein GP-150 in neutrophil adherence to endothelium in vivo. Blood $1985 ; 66$ : 167-78.

23 Beatty PG, Harlan JM, Rosen H et al. Absence of monoclonal antibody defined protein complex in boy with abnormal leukocyte function. Lancet 1984; i: 535-7.

24 Gabius $H$-J. Endogenous lectins in tumors and the immune system. Cancer Invest 1987; 5: 39-46.

25 Kieda CMT, Bowles DJ, Ravid A, Sharon N. Lectins in lymphocyte membranes. FEBS Lett 1978; 94: 391-6.

26 Gabius H-J, Nagel GA. (Eds.). Lectins and Glycoconjugates in Oncology. New York: Springer Verlag, 1988.

27 Czop JK. The role of $\beta$-glucan receptors on blood and tissue leukocytes in phagocytosis and metabolic activation. Pathol Immun Res 1986; 5: 286-96.

28 Rottini G, Cian F, Soranzo R et al. Evidence for the involvement of human polymorphonuclear leukocyte mannose-like receptors in the phagocytosis of Escherichia coli. FEBS Lett 1979; 105: 307-12.

29 Silverblatt FJ, Dreyer JS, Schauer S. Effect of pili on susceptibility of Escherichia coli to phagocytosis. Infect Immun 1979; 34: 218-23.

30 Stahl PD, Rodman JS, Miller MJ et al. Evidence for receptor-mediated binding of glycoproteins, glycoconjugates and lysosomal glycosidases by alveolar macrophages. Proc Natl Acad Sci USA 1978; 75: 1399-403.

31 Sepherd VL, Lee YC, Schlesinger PH et al. L-fucose terminated glycoconjugates are recognized by pinocytosis receptors on macrophages. Proc Natl Acad Sci USA 1981 78: 1019-22.

32 Bardosi L, Bardosi A, Hendrys $M$ et al. Reduced expression of mannose-specific receptors on murine peripheral blood polymorphonuclear leukocytes following prolonged anaesthesia with different inhalation agents. Acta Anaesthesiol Scand 1990; 34: 286-90. 